\title{
Predictive risk model of livestock rabies occurrence in Peru
}

\author{
Modelo de risco preditivo para a ocorrência da raiva bovina no Peru
}

\author{
Francisco Miroslav Ulloa-Stanojlovic ${ }^{1}$; Ricardo Augusto Dias ${ }^{1}$ \\ ${ }^{1}$ Universidade de São Paulo, Faculdade de Medicina Veterinária e Zootecnia, Departamento de Medicina Veterinária Preventiva e Saúde \\ Animal, São Paulo - SP, Brazil
}

\begin{abstract}
Livestock rabies is endemic in Peru. Hence, its persistence and annual dissemination represent an important economic impact, especially for impoverished farming communities. The disease is mostly transmitted by the hematophagous bat Desmodus rotundus. The present study aimed to adapt an existing predictive model of the occurrence of livestock rabies to Peru, in which the risk of rabies transmission from bats to livestock was estimated using decision-tree models of receptivity and vulnerability. Official rabies surveillance data between 2010 and 2015 were used along with possible risk factors, such as livestock biomass, environmental changes, and geomorphological characteristics. Several scenarios were established to evaluate the prediction of the occurrence of livestock rabies cases by determining more than one cut-off point of the receptivity variables. During the study period, the precision of the model was estimated through the sensitivity (39.46\%) and specificity $(98.64 \%)$ by using confusion matrices. Targeting control efforts, especially in districts with a high estimated risk, could represent the prevention of a significant proportion of livestock rabies cases, which would optimize the human and economic resources of the Peruvian surveillance service. However, the quality of data produced by the surveillance should be improved not only to obtain higher model precision but also to allow the adequate planning of control actions.
\end{abstract}

Keywords: Desmodus rotundus. Peru. Predictive model. Rabies. Vampire bat.

\section{RESUMO}

Raiva de herbívoros é endêmica no Peru. Consequentemente, sua disseminação persistente e anual representa um importante impacto econômico, especialmente às comunidades rurais empobrecidas. A doença é principalmente transmitida pelo morcego hematófago Desmodus rotundus. Este estudo tem por objetivo adaptar um modelo preditivo pré-existente às ocorrências de raiva de herbívoros no Peru, no qual o risco de transmissão de morcegos para os herbívoros foi estimado por meio de árvores de cenários de receptividade e vulnerabilidade. Foram usados os dados oficiais de vigilância da raiva entre 2010 e 2015, assim como os possíveis fatores de risco, tais quais a biomassa de animais, alterações ambientais e características geomorfológicas. Diversos cenários foram criados para avaliar a predição da ocorrência da raiva por meio da determinação de diversos pontos de corte das variáveis de receptividade. Durante o período de estudo, a precisão do modelo foi estimada por meio da sensibilidade (39,46\%) e especificidade $(98,64 \%)$, utilizando matrizes de confusão. Focando em esforços de controle, especialmente em distritos com elevado risco estimado, seria possível prevenir uma proporção significativa dos focos, o que poderia otimizar os recursos humanos e econômicos do serviço oficial peruano. Entretanto, a qualidade dos dados produzidos pelo sistema de vigilância deveria ser melhorada não somente para obter maior precisão do modelo, mas também para possibilitar o melhor planejamento das ações de controle desta doença.

Palavras-chave: Desmodus rotundus. Peru. Modelo preditivo. Raiva. Morcego vampiro. 
Correspondence to:

Ricardo Augusto Dias

Universidade de São Paulo, Faculdade de Medicina Veterinária

e Zootecnia, Departamento de Medicina Veterinária

Preventiva e Saúde Animal

Av. Professor Doutor Orlando Marques Paiva, 87

CEP: 05508-270, Cidade Universitária, São Paulo - SP, Brazil

e-mail: ricardodias@usp.br

Received: March 17, 2021

Approved: July 12, 2021

How to cite: Ulloa-Stanojlovic FM, Dias RA. Predictive risk model of livestock rabies occurrence in Peru. Braz J Vet Res Anim Sci. 2021;58:e183270. https://doi.org/10.11606/ issn.1678-4456.bjvras.2021.183270

\section{Introduction}

Rabies is a zoonotic disease caused by a ribonucleic acid (RNA) virus belonging to the genus Lyssavirus of the family Rhabdoviridae. The rabies virus (RABV) has a large number of domestic and wild mammal hosts, one of the main reasons it is still endemic in several world regions (Davis et al., 2015). In Latin America, three hematophagous bat species are found:Desmodus rotundus (E. Geoffroy, 1810), Diphylla ecaudata (Spix, 1823), and Diaemus youngii (Jentink, 1893). The first, known as the common vampire bat, is the main host responsible for the transmission of RABV (Johnson et al., 2014), and the other two more frequently prey upon birds. The most important and abundant hematophagous bat in the region is D. rotundus (Belotto et al., 2005). This bat feeds mostly on blood from bovines, horses, goats, swine, sheep, and other mammalians, including humans (Goodwin \& Greenhall, 1961), and the consequence may be the transmission of the RABV Mayen (2003). These animals use caves, rifts, or hollow trees as natural roosts, or due to the spread of deforestation and the fragmentation of their natural environments, they use artificial roosts such as abandoned buildings, bridges, or sewer ducts (Gomes \& Uieda, 2004). Environmental characteristics such as the terrain relief may indicate the presence of caves or other natural concavities, and forest remnants can also be important predictors of natural roosts (Brasil, 2009).

As a result of the decrease in human rabies cases transmitted by dogs, the proportion of cases transmitted by bats increased in the decade of 2000, an important change in the epidemiological profile in most Latin American countries (Schneider et al., 2009). In Peru, economic losses due to bovine rabies have been estimated at more than US $\$ 300,000$ per year due to animal mortality and vaccination costs. This results in an excessively high economic impact for a developing country where the impoverished farming communities that rely on livestock for subsistence are the most affected (Benavides et al., 2017).

Evidence of the population dynamics of the vampire bats on the transmission of RABV to livestock results in temporary epidemic waves in Peru, especially in the inter-Andean valleys (Benavides et al., 2017). The possible associated factors are the availability of food sources and the reduction of natural habitats due to environmental changes affecting the distribution of $D$. rotundus and the presence of natural or artificial roosts (Johnson et al., 2014). Although not described as a migratory species and usually living in areas below 1,800 meters above sea level (masl), D. rotundus can inhabit higher altitudes if there is food availability, even if limited, as occurs along the inter-Andean valleys, an important livestock area of Peru. This region has an average altitude higher than 2,000 masl and is currently experiencing rabies epidemics (Condori-Condori et al., 2013). Hence, the distribution and density of livestock, as well as the livestock biomass, which is more in line with the support capacity of the environment for these bats than the livestock herd size itself, could be considered important predictors of the presence of vampire bats.

Since 2003, the Peruvian National Agrarian Health Service (SENASA) has maintained records of the locations and dates of rabies cases in cattle, horses, pigs, and small ruminants. The animal rabies surveillance system is passive and is responsible for the detection and monitoring of rabies cases associated with bats and other wild animals. For that reason, this system depends on whether suspicious symptoms in livestock or vampire bat attacks reported by the producers to the regional offices of SENASA. After clinical evaluations are carried out by the official veterinarians, samples are collected and sent to SENASA's animal health reference laboratory or another authorized laboratory. Control measures include the mandatory vaccination of all susceptible livestock in a $5 \mathrm{~km}$ focal area and eligible vaccination in a $25 \mathrm{~km}$ perifocal area around the outbreak.

Operationally, the Peruvian animal rabies surveillance system for livestock is not ideal because it lacks predictive actions to prevent new outbreaks. Brazil already has a system where qualitative risk models of rabies cases are available to predict rabies outbreaks in high-risk areas, and the allocation of limited human and logistic resources contributes to livestock rabies control (Braga et al., 2014; Dias et al., 2011). The main objective of the present study is to provide a methodology to the Peruvian national surveillance service for estimating the risk of rabies transmission from vampire bats to livestock at the district level using official records and environmental data. 


\section{Materials and Methods}

\section{The general design of the model}

For the development of the study, an algorithm of risk estimation based on the concept of receptivity and vulnerability previously described in Brazil was used (Braga et al., 2014; Dias et al., 2011). In the Brazilian model, the epidemiological units were the farms and municipalities, respectively, but in the present work, the 1,833 districts of Peru were considered as the epidemiological units. The Peruvian districts are administrative divisions similar to the Brazilian municipalities.

According to Dias et al. (2011), receptivity was defined as a set of variables that expressed the ability of the ecosystem to maintain vampire bat populations related to the availability of food and shelter, while vulnerability represented a set of variables related to RABV circulation in the region and the possibility of spreading to new areas. In the Peruvian model, the variables chosen for receptivity were livestock biomass (explained below) and environmental predictors of bat roost presence, such as relief slope and proportion of forest remnants, by districts in 2010. The variables chosen for vulnerability were the occurrence of livestock (cattle, horses, swine, and small ruminants) rabies cases and the occurrence of environmental changes by the district.

Based on the studies by Dias et al. (2011) and Braga et al. (2014), the levels of receptivity and vulnerability by district were estimated using decision trees established according to the obtained data, which were provided mainly by SENASA and the last national agricultural census (CENAGRO) by the National Institute of Statistics and Informatics (Instituto Nacional de Estadística e Informática, 2012). Despite the inability to obtain information about the presence of bat roosts and the presence of vampire bats and/or other species of wild animals positive for RABV, both variables were kept to maintain the original structure of the model and to facilitate the future inclusion of this information.

\section{Receptivity}

The livestock biomass, hereafter called animal unit (AU), was based on an animal of approximately 1,000 pounds ( $450 \mathrm{~kg}$ ), a concept widely used to evaluate the management of livestock grazing (Society for Range Management Rangeland Assessment and Monitoring Committee, 2017). The AU was evaluated by first multiplying by the livestock populations (cattle, horses, pigs, and small ruminants) and then adding them up and obtaining a total value. To achieve that, the herd numbers were obtained from the last CENAGRO census of 2012. Next, the herd was multiplied by a factor according to the livestock species: cattle $=1 \mathrm{AU}$, horses $=1.5 \mathrm{AU}$, pigs $=0.3 \mathrm{AU}$, and small ruminants $=0.2 \mathrm{AU}$ (Society for Range Management Rangeland Assessment and Monitoring Committee, 2017). Finally, the AU values for all species were summed to obtain a total AU by the district. To transform this variable into a binary variable, three cut-off points of the distribution, the first quartile (25\%), the median, and the third quartile $(75 \%)$ were arbitrarily chosen.

The relief slope and the proportion of forest remnants were considered predictors of vampire bat roost existence. A digital elevation model (DEM) of Peru obtained from the United States Geological Survey (2020) was used to produce a slope map of the country using the open-source software QGIS version 2.18 (QGIS Development Team, 2016). The average value of the relief slope by the district was obtained using the zonal statistics plugin of the QGIS software. This quantitative variable was transformed into a binary variable the same way as the AU.

The proportion of forest remnants was obtained in the Global Forest website (University of Maryland, 2016) as a raster, which was coded as a percentage per exit grid cell, ranging from 0 to 100 . It is noteworthy that there has been a significant loss of forest cover since the year that information was obtained (2010) but not enough to compromise this work (Hansen et al., 2013). Furthermore, to extract the average values of forest remnants by district, the statistical package raster in $\mathrm{R}$ was used. Moreover, this quantitative variable was transformed into a binary variable the same way as the AU.

The proportion of forest remnants and relief slope, which were originally quantitative, were combined into a single dichotomous predictive variable of roosts called 'environmental features'. At the same time, as a result of the three cut-off points determined for each variable, different combinations of the two variables were established, where for each combination if both variables were above the cut-off points, the districts were classified as 'presence of environmental features'. Otherwise, they were classified as 'absence of environmental features'.

Therefore, with the existence of three cut-off points for $\mathrm{AU}$ and the different combinations of the environmental features previously established, it was possible to create different scenarios that allowed evaluating the best possible combination to describe the receptivity. The decision tree for receptivity is shown in Figure 1. 


\section{Vulnerability}

The records of suspected livestock (bovines, horses, pigs, and small ruminants) rabies cases were compiled from the official database of weekly epidemiological reports of SENASA from 2010 to 2015. For this work, a livestock rabies case was confirmed by laboratory diagnosis as a result of the surveillance carried out by SENASA. Despite the number of cases by district, if at least one case was recorded, the given district was considered to have a 'rabies occurrence.' Otherwise, it was considered to have a 'rabies absence.' Although the number of rabies cases per district was kindly provided by SENASA, the number of rabies diagnoses was not available.

Moreover, the occurrence of environmental changes per district was obtained through the information available on the Internet, especially major engineering projects such as dams, gas pipelines, mineral extraction plants, roads, railways, large-scale agricultural activities, and seasonal livestock movements. These activities were considered 'environmental changes' and could influence the entry or exit of vampire bat populations in a given district. The decision tree for vulnerability is shown in Figure 2.

\section{Combination of receptivity and vulnerability}

It was possible to evaluate the risk of rabies for each district as a result of the combination of the results of the decision trees for receptivity and vulnerability using the matrix originally described by Dias et al. (2011), which establishes that the risk levels are negligible, low, medium and high, as presented in Table 1.

\section{Model validation}

The districts where it was not possible to obtain information on livestock populations were discarded. A total of 27 different scenarios, each with a set of risk categories, were made due to the combination of the three cut-off points selected in the receptivity. Each scenario was compared to the livestock rabies reports of the following year in a study period of six years (2010 to 2015). Hence, this allowed the elaboration of confusion matrices for all scenarios for each year to evaluate their accuracy, sensitivity, and specificity to determine an adequate level of prediction of rabies cases. Finally, several thematic risk maps of the districts were created using QGIS software.

Moreover, the proportion of outbreaks located in high-risk areas was obtained to check the effectiveness of the prioritization of rabies control in these areas.

\section{Results}

\section{Receptivity}

Of the 1,833 districts of Peru, the cattle population was not available for $31(1,7 \%)$, due to the creation of new

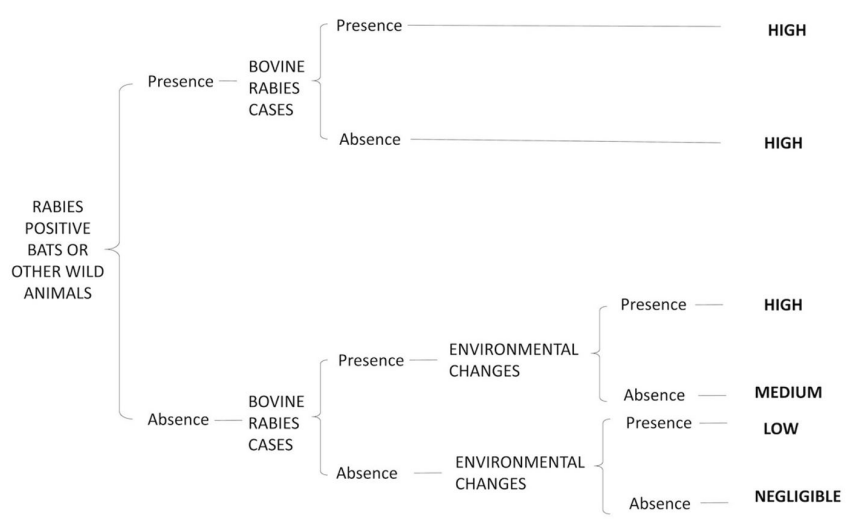

Figure 2 - Decision tree used to estimate the vulnerability to rabies virus circulation and its spread to new areas in Peru. Source: adapted from Dias et al. (2011).

Table 1 - Association matrix of estimation of livestock rabies risk based on receptivity and vulnerability

\begin{tabular}{cccccc}
\hline & & \multicolumn{3}{c}{ Receptivity } \\
\cline { 3 - 6 } & & Negligible & Low & Medium & High \\
\hline Vulnerability & Negligible & Negligible & Low & Low & Medium \\
& Low & Low & Low & Medium & Medium \\
& Medium & Low & Medium & Medium & High \\
& High & Medium & Medium & High & High \\
\hline
\end{tabular}

Source: adapted from Dias et al. (2011). 
districts. In those cases, we only considered the population of the original district. The distribution of the AU was normal, and the cut-off points were 1,390 AU (first quartile, Figure 3a - map A), 3,348 AU (median, Figure 3a - map B), and 7,026 AU (third quartile, Figure $3 a-$ map C).

Regarding the environmental changes' variables, i.e., forest remnants, the data distribution was also normal, and the cut-off points were $0.11 \%$ (first quartile, Figure $3 \mathrm{~b}-$ map D), 2.95\% (median, Figure 3b - map E) and 19.12\% (third quartile, Figure $3 b-$ map F).

Meanwhile, the data distribution of the relief slope values was also normal, and the cut-off points were 7.73 (first quartile, Figure 3c SM - map G), 16.32 (median, Figure 3c - map H), and 27.17 (third quartile, Figure $3 c$ - map I).

\section{Vulnerability}

The yearly distribution of the livestock rabies cases is shown in Figure 4, which represents a national overview of livestock rabies. As observed in Figure 4, the rabies cases were recorded primarily in the central region of Peru (Andean valleys) and few cases in the Amazon region, throughout the years. Moreover, the districts where environmental changes were recorded in the same period are shown in Figure 5.

\section{Risk estimation}

As a result of the three cut-off points for the receptivity variables, all combinations were considered, resulting in 27 possible scenarios (Figure 6). The different risk levels for the occurrence of livestock rabies by the district for the years 2016 and 2017, established by several combinations and based on the arbitrary cut-off points, are shown in Figure 7. It should be highlighted that the highest category shows more consistency in prediction in the different scenarios, and there were many districts classified with a negligible risk in the most extreme combinations (333) for the prediction of livestock rabies occurrence at the national level.

\section{Model validation}

The results of the confusion matrices generated from the comparisons of the various combinations previously described and their respective risk categories associated with the rabies cases of the following year are shown in Table 2. The results showed that between 2010 and 2015, the best
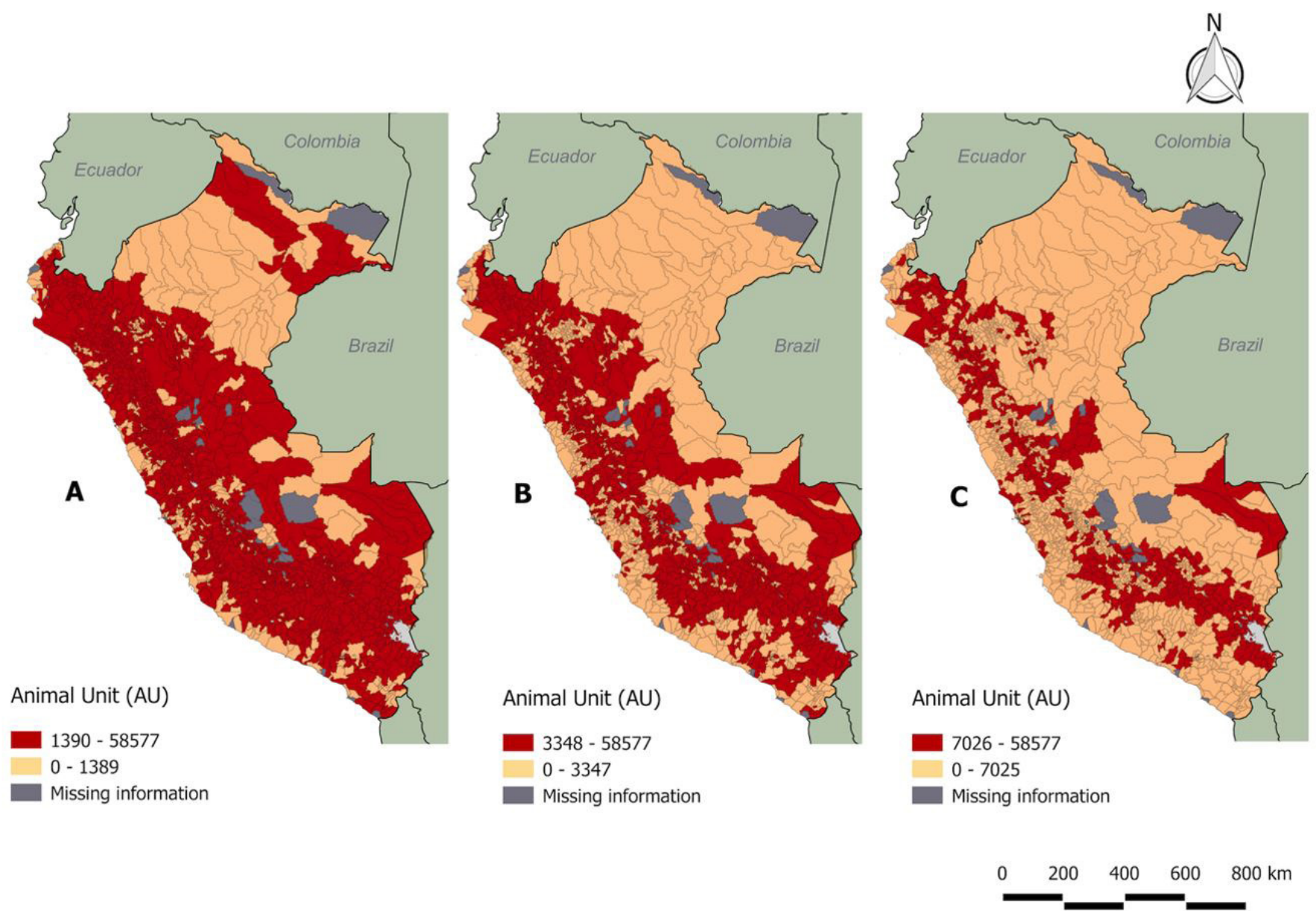

Figure 3a-Selected cut-off points of animal unit (AU) parameter, Peru, 2012. 


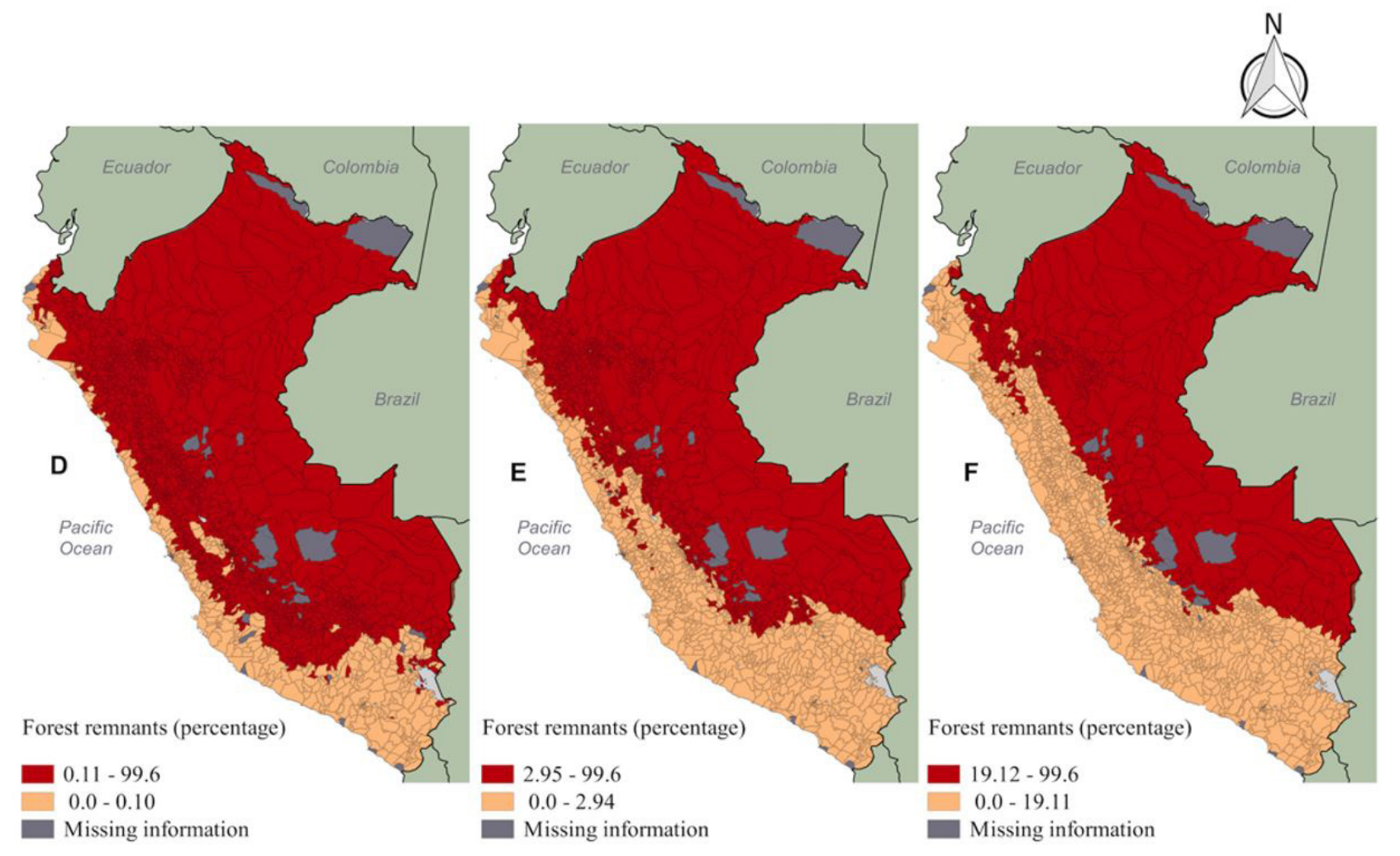

$0 \quad 200 \quad 400 \quad 600 \quad 800$
$\mathbf{k m}$

Figure $3 b$ - Selected cut-off points of forest remnants, Peru, 2010.

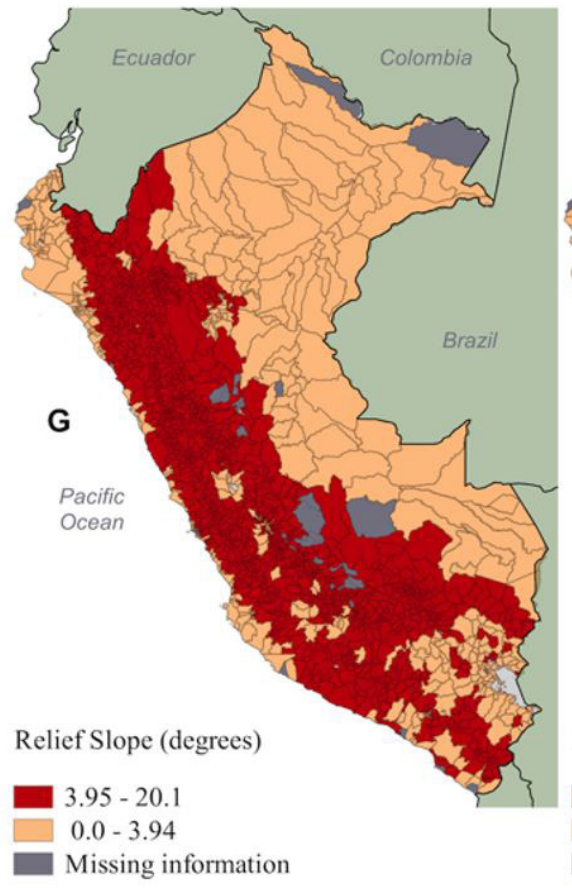

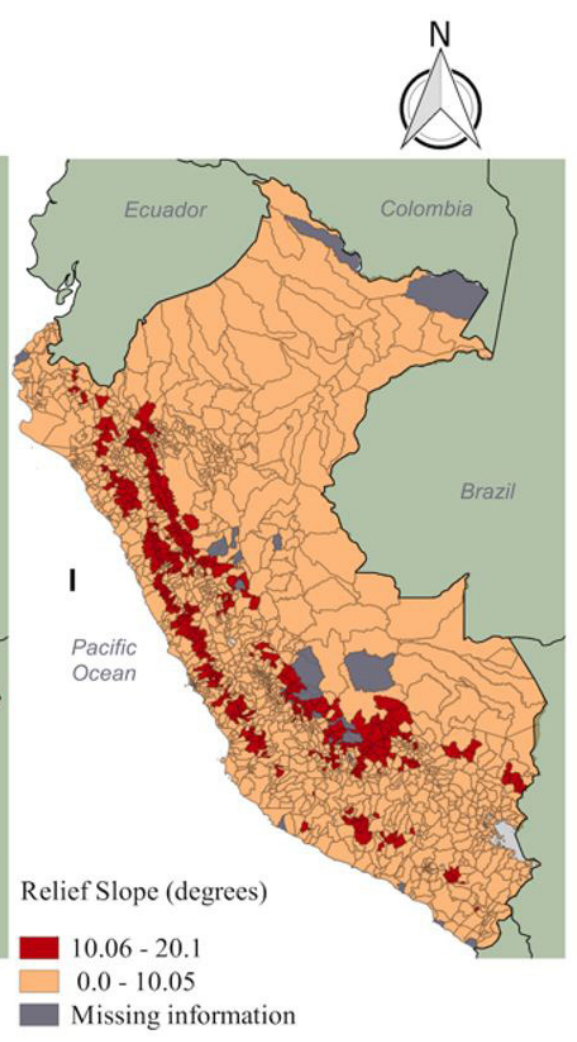

$\begin{array}{lllll}0 \quad 200 & 400 \quad 600 \quad 800 & \mathrm{~km}\end{array}$

Figure $3 c$ - Selected cut-off points of the relief slope, Peru, 2011. 


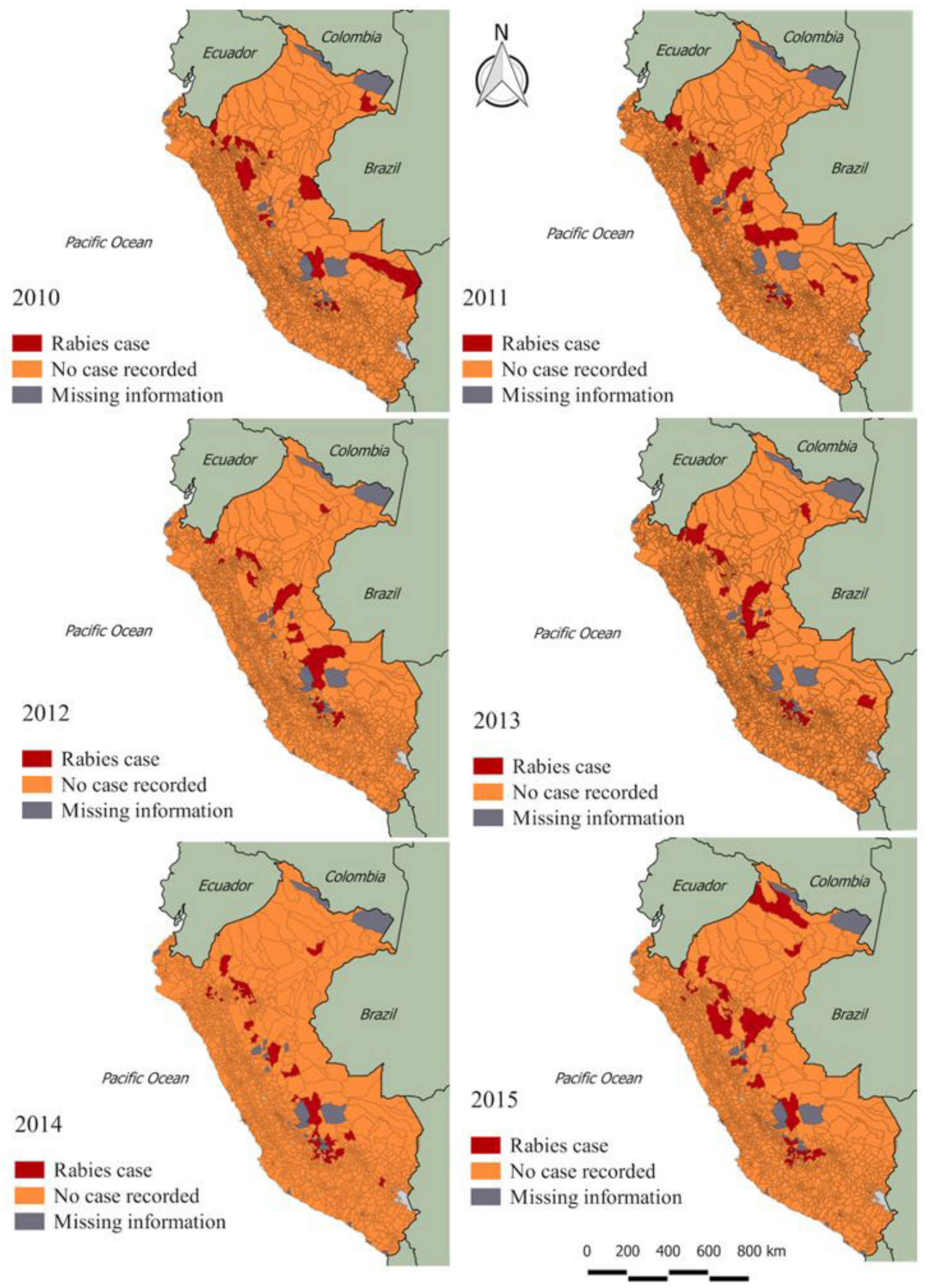

Figure 4 - Spatial distribution of livestock rabies cases, 2010-2015, Peru. 


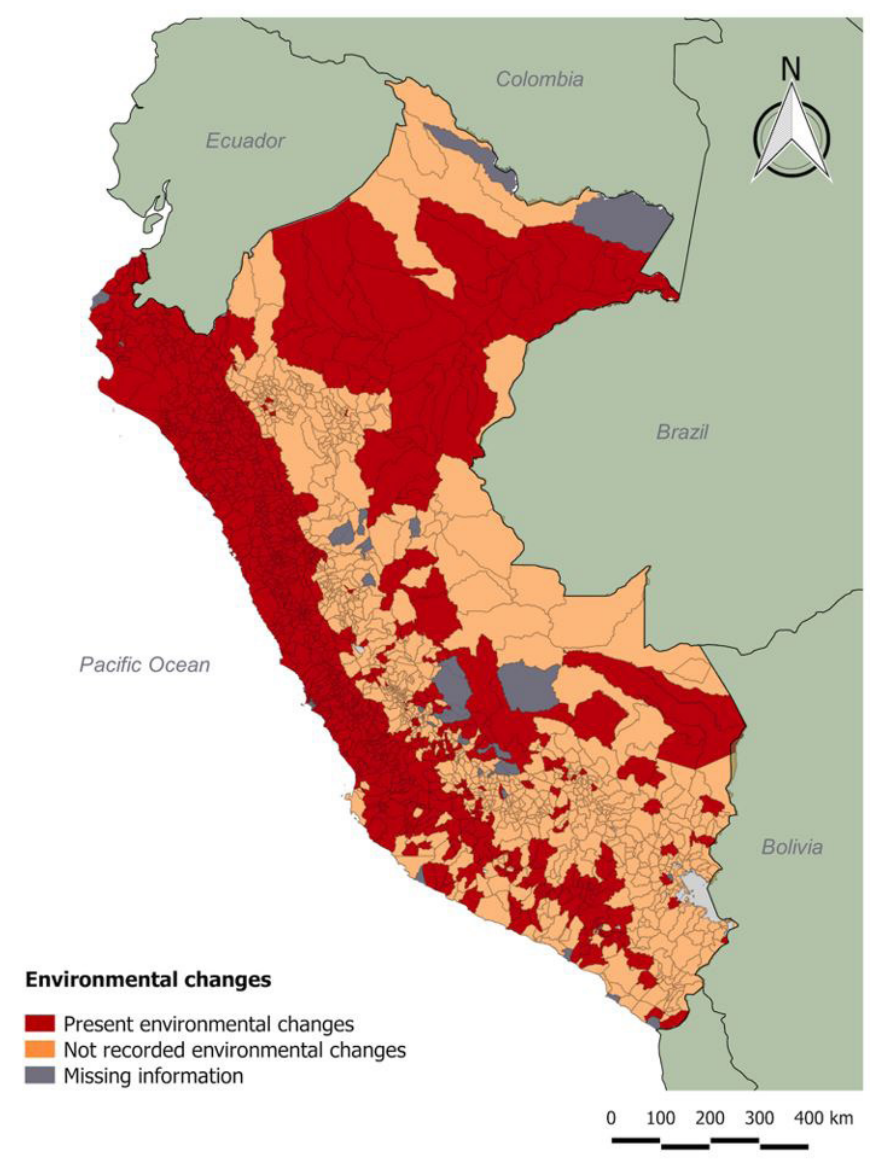

Figure 5 - Map of the districts where environmental changes were identified, 2010-2015, Peru.

prediction with the best possible combination (121) had an average accuracy of $96.9 \%$ and a specificity of $98.6 \%$. Otherwise, there was an average sensitivity of $39.3 \%$.

Finally, if the control measures were implemented in the districts with a high risk the livestock rabies cases would be reduced by between 29.1 and $48.6 \%$ at the national level.

\section{Discussion}

This model was adapted from the studies of Dias et al. (2011) and Braga et al. (2014), who used data from the rabies surveillance system of Brazil, where the model is currently executed in some regions of the country. When applied to Peru, it could also be used in the national surveillance of livestock rabies and most likely in other Latin American countries with similar epidemiological situations and surveillance capacity.

The model is based on the concept that understanding the ecological patterns, frequency and spatial distribution of the infected vampire bats is important to predict the dissemination of infectious diseases such as rabies (Bourhy et al., 2010). Some authors point out that the combination of concepts such as the genetics of the host population, the phylogeography of pathogens, and landscape ecology can also help to predict the rates and routes of invasion of pathogens to areas without the presence of the disease (Streicker et al., 2016). The existence of a large distribution of vampire bat populations could be a result of a high livestock density (Becker et al., 2018; Lee et al., 2012) since it has been reported that the vampire bats have a greater predilection to prey upon livestock compared to wild animals or humans (Gilbert et al., 2012; Streicker \& Allgeier, 2016; Voigt \& Kelm, 2006). Extensive livestock raising is the most common type in Peru (Rosemberg, 2018); consequently, the sizes of the herds and the passive behavior of the livestock facilitate foraging by vampire bats. This situation is even more facilitated by humans limiting the movement of livestock at night by keeping them in pens (Voigt \& Kelm, 2006). Likewise, it has been reported that the most common prey of the vampire bats are cattle and horses (Mialhe, 2014), corroborated by the present work, where the largest proportion of cases of the time interval evaluated was in cattle (83.47\%) followed by horses (9.21\%). Otherwise, using the AU parameter instead of the cattle density as described by Dias et al. (2011), was a more appropriate approach for the Peruvian reality, since the livestock raising is most extensive and several domestic species are raised together. Moreover, since vampire bats preference to prey upon domestic mammals over native fauna which is less associated with their density (Bobrowiec et al., 2015; Voigt \& Kelm, 2006), the livestock biomass availability was the preferable approach.

Although the vampire bat population in Peru has been submitted to intense culling through the use of an anticoagulant paste, no positive effects of control and reduction of the frequency of rabies have been observed (Streicker et al., 2012). It is even possible that this practice has caused disruptions of the bat colonies, resulting in higher infectious contacts and thus causing the increased spillover of the RABV to livestock. Therefore, in the absence of rabies positive bat records or active searches for roosts, due to low budget and logistics, it would be interesting in the future to include other kinds of environment variables that should be easy to obtain and that could represent an adequate cost-benefit for the system, such as the frequencies of bat attacks on livestock. This approach would allow the evaluation of the foraging intensity on these animals and the potential risk of rabies transmission, especially in regions where there are recent records of the circulation of RABV.

The forest remnants and the relief slope are characteristics that provide the necessary conditions for the establishment of natural roosts for different bat species, including the common vampire bat (Estrada et al., 2004; Medina et al., 


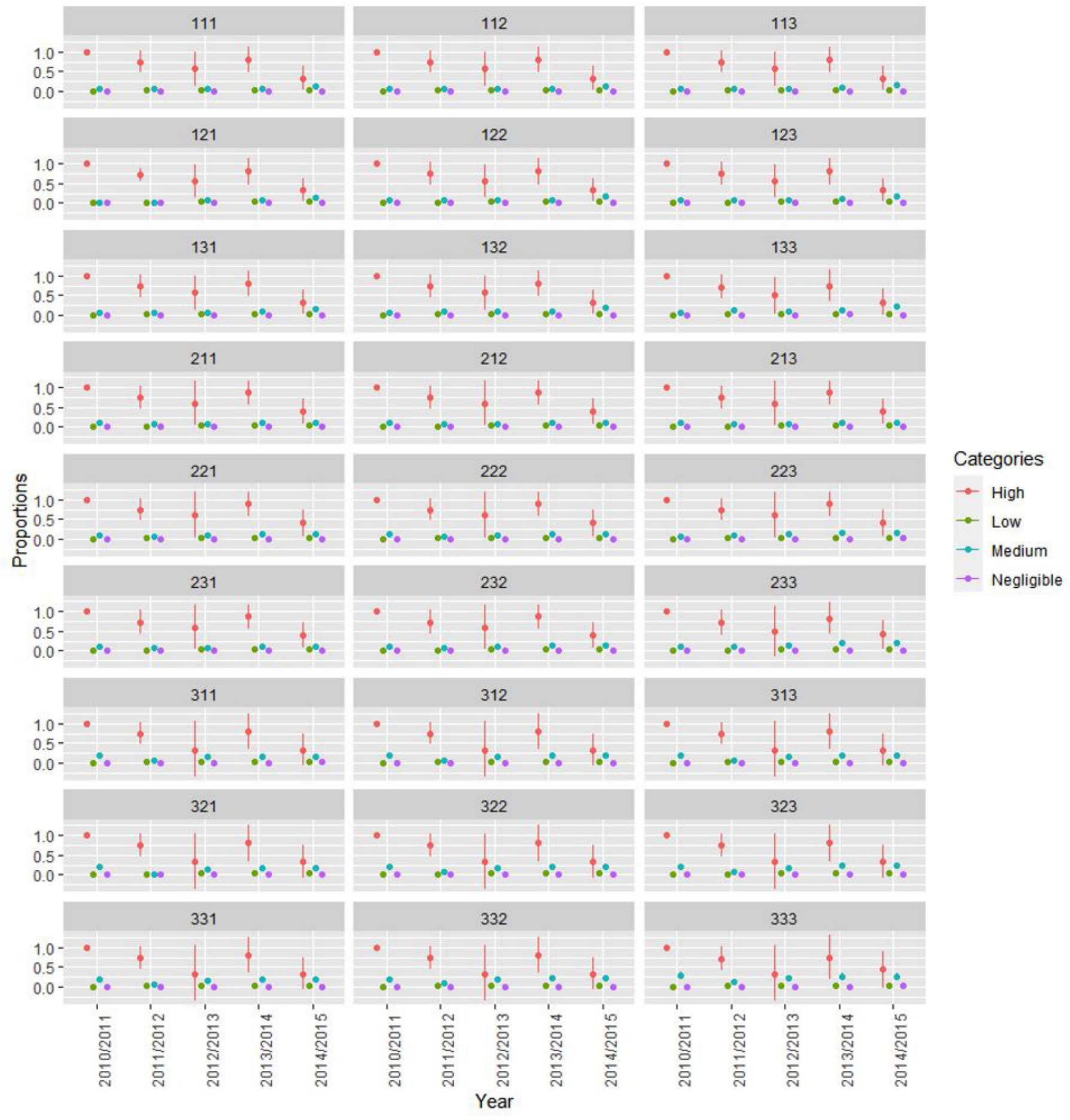

Figure 6 - Matrix of confidence intervals (95\%) of the proportions of the quantitative risk categories along with the livestock rabies occurrence in Peru from 2010 to 2015.

2007). Apart from caves, the main natural roost for the common vampire bat, other natural roosts include tree holes, and deep cracks in rocks, among others (Bredt et al., 1998). The relief slope is a suitable predictor for caves, an important vampire bat roost (Braga et al., 2014; Dias et al., 2011), especially in a country with geography as rugged as Peru. Most caves are located close to livestock grazing, they can be used by these bats as roosts, allowing them to move easily between the roosts and the available livestock for feeding. This travel distance can affect both the duration and the temporal course of the foraging (Erkert, 1982; Gomes \& Uieda, 2004) and the vampire bats use river systems and remnants or small riparian forests as references to accomplish these foraging movements (Medina et al., 2007). Moreover, the common vampire bats can use a great diversity of human-made structures as artificial roosts, including sewers, bridges, and abandoned homes, among others, that can provide shelter. 
A

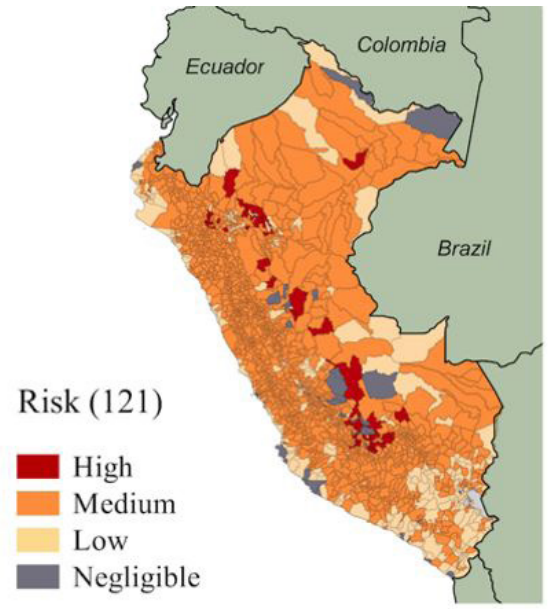

B

Risk (121)
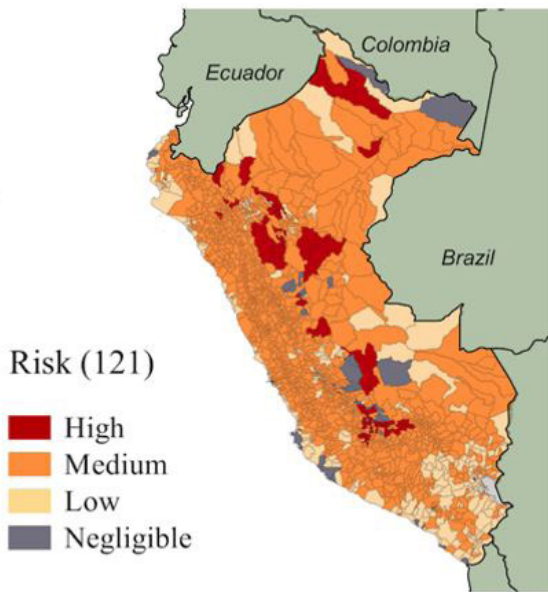
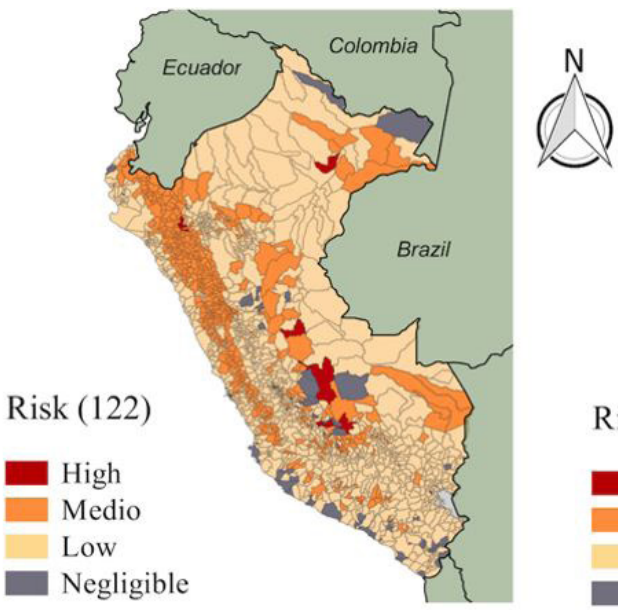

Risk (333)
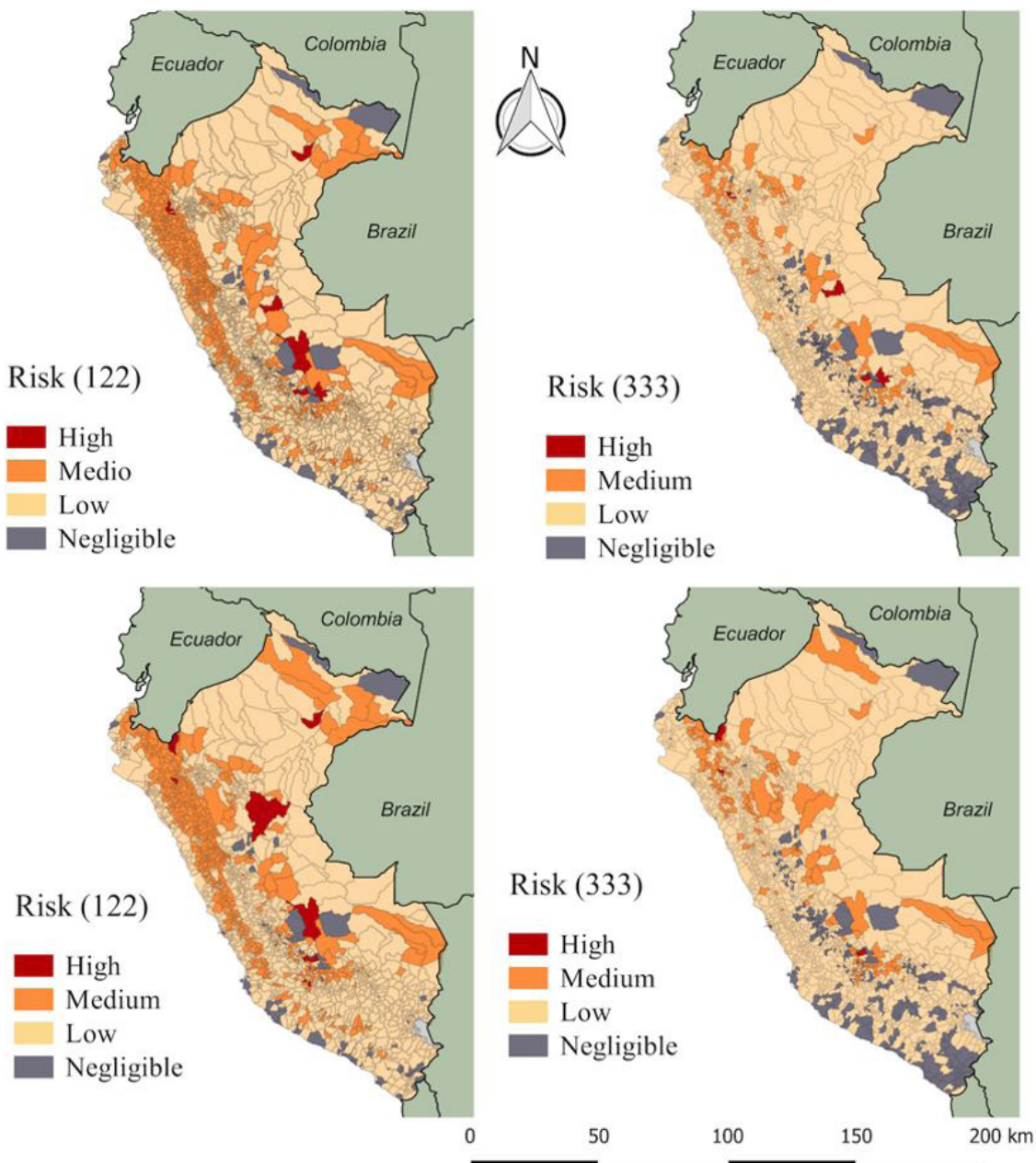

Figure 7 - The estimated risk for the occurrence of livestock rabies cases by the district for the years 2014 (A) and 2015 (B), Peru.

Table 2 - Analysis of sensitivity, specificity, and accuracy through confusion matrices of the risk categories for the prediction of the occurrence of cases in livestock rabies, Peru, 2010-2015

\begin{tabular}{|c|c|c|c|c|c|}
\hline & $2010-2011^{\text {(c) }}$ & $2011-2012^{(\mathrm{c})}$ & $2012-2013^{(\mathrm{c})}$ & 2013-2014(c) & $2014-2015^{\text {(c) }}$ \\
\hline \multicolumn{6}{|l|}{$121^{(a, b)}$} \\
\hline Sensitivity (\%) & 36.8 & 48.6 & 29.1 & 40.3 & 41.7 \\
\hline Specificity (\%) & 98.5 & 98.9 & 98.9 & 98.7 & 98.2 \\
\hline Accuracy (\%) & 97.2 & 97.9 & 96.7 & 96.6 & 95.9 \\
\hline $\mathrm{PPV}^{(\mathrm{d})}$ & 34.1 & 50 & 44.4 & 55.1 & 49.2 \\
\hline NPV (e) & 98.6 & 98.6 & 97.8 & 97.7 & 97.6 \\
\hline \multicolumn{6}{|l|}{$122^{(a, b)}$} \\
\hline Sensitivity (\%) & 7.89 & 16.1 & 10.9 & 4.8 & 5.6 \\
\hline Specificity (\%) & 99.6 & 99.7 & 99.6 & 99.5 & 99.5 \\
\hline Accuracy (\%) & 98.9 & 98.1 & 96.9 & 96 & 95.7 \\
\hline $\mathrm{PPV}^{(\mathrm{d})}$ & 30 & 60 & 46.2 & 27.3 & 30.8 \\
\hline NPV (e) & 98.1 & 98.2 & 97.3 & 96.4 & 96.2 \\
\hline
\end{tabular}

Anthropic environmental changes, such as the construction of roads, dams, railways, gas pipelines, oil pipelines, and untimely shifts between agricultural and grazing areas, may change the distribution of food sources and consequently the vampire bat colonies' structures, increasing their dispersion to other areas (Estrada \& Coates-Estrada, 2002;
Kingston, 2013; Mayen, 2003). This situation, in which the main transmitters of the RABV are subjected to habitat disturbance, has an important impact on the dissemination of the disease to free areas. Unfortunately, the information for this variable was obtained only through Internet searches for the available documents, some not official or recent, and 
no information was found on the occurrence of alterations in many districts nationwide. Thus, this information is probably incomplete.

The model is highly dependent on the quality of the data, especially those related to vulnerability, such as the notification of bovine rabies cases (Braga et al., 2014; Dias et al., 2011). This dependence results from the health education of the owners and the promptness of the disease surveillance service, which is responsible for investigating and diagnosing rabies suspicions. There is a high rate of underreporting of the disease in the country, which has been estimated to be four times higher than the officially reported rate (Benavides et al., 2017). Thus, it is necessary to urgently promote health education campaigns among owners at a national level, as it would not only allow notifications to increase and resemble real data but also allow the improvement of surveillance systems through the development of more effective control strategies, decision making and a better orientation of surveillance efforts.

The presence of bat roosts (receptivity-related) and bats or other wild animals positive for the RABV (vulnerabilityrelated) were variables found in the original decision trees proposed by Dias et al. (2011) and Braga et al. (2014), but there were none included since the Peruvian surveillance service does not collect them. Although these variables were not available, we decided to keep them in the decision trees of the model to preserve the methodology and facilitate a possible future insertion. Moreover, the 'environmental features' variable (conjunction of forest remnants and relief slope variables) may indicate the presence of bat roosts, which can help, especially in a country where there is not yet an official registry.

Through the use of the confusion matrices, it was possible to determine the levels of sensitivity and specificity of the model, which were not constant in all the years evaluated. Throughout the study period, the sensitivity was below $50 \%$ leading to a low positive predictive value, caused by the low numbers of livestock rabies notifications. Nonetheless, if the control measures were implemented in the districts with a high risk the livestock rabies cases would be reduced, allowing the appropriate allocation of the control measures and the resources of the surveillance service. These parameters were not calculated by Braga et al. (2014). If this model is to be used in the rabies surveillance and control in Peru, it could be updated with more recent information and more importantly, the completion of the missing information of some districts, improving its precision.

The goal of the model was to be a simple tool that could be incorporated into the routine of the livestock rabies surveillance service of SENASA to prevent the presentation of cases in the country by optimizing the allocation of logistical and human resources through the implementation of control and prevention strategies of the disease, using the data from the surveillance system. This approach can be soon adapted to a new program of rabies surveillance in herbivores at the national level. It is important to highlight the need to update the information every year and to promote and improve the collection, management, and information systems of the national rabies surveillance.

In conclusion, even showing a low precision and positive predictive value, the proposed model could be used as a tool by the Peruvian rabies surveillance system to aid in the prediction of cases of livestock rabies transmitted by vampire bats, optimizing intervention strategies, such as human and logistic resources, for the areas with the highest risk of cases. This can be inferred by the potential decrease in the prevalence if control measures were deployed in high-risk areas. However, the model depends on highquality information to achieve good precision in the results. Therefore, the surveillance system needs to guarantee the logistical resources for correct data collection and execution for control actions of rabies.

\section{Conflict of Interest}

The authors declare no conflict of interest.

\section{Ethics Statement}

We certify that the project entitled "Evaluación descriptiva de la rabia humana y animal, y desarrollo de un modelo predictivo de rabia bovina en el Perú", registered with n. 1438150917, which does not involve the use of animals, under the responsibility of Ricardo Augusto Dias, was approved by the Ethic Committee in the Use of Animals of School of Veterinary Medicine and Animal Science (University of São Paulo), in a meeting of October 252017.

\section{Acknowledgements}

The authors would like to thank Jorge Mantilla from the National Service of Animal Health (SENASA) for helping to clarify some doubts about the official information. Francisco Miroslav Ulloa-Stanojlovic was supported by the National Fund for Scientific, Technological Development and Technological Innovation (FONDECYT), the funding branch of the National Council for Science, Technology and Technological Innovation (CONCYTEC) Peru (Grant No. 003-2016-FONDECYT). This study was financed in part by the Coordination for the Improvement of Higher Education Personnel (CAPES) - Finance Code 001. 


\section{References}

Becker DJ, Czirják GA, Volokhov DV, Bentz AB, Carrera JE, Camus MS, Navara KJ, Chizhikov VE, Brock Fenton M, Simmons NB, Recuenco SE, Gilbert AT, Altizer S, Streicker DG. Livestock abundance predicts vampire bat demography, immune profiles and bacterial infection risk. Philos Trans R Soc Lond B Biol Sci. 2018;373(1745):20170089. http:// dx.doi.org/10.1098/rstb.2017.0089. PMID: 29531144.

Belotto A, Leanes LF, Schneider MC, Tamayo H, Correa E. Overview of rabies in the Americas. Virus Res. 2005;111(1):512. http://dx.doi.org/10.1016/j.virusres.2005.03.006. PMid:15896398.

Benavides JA, Rojas Paniagua E, Hampson K, Valderrama W, Streicker DG. Quantifying the burden of vampire bat rabies in Peruvian livestock. PLoS Negl Trop Dis. 2017;11(12):e0006105. http://dx.doi.org/10.1371/journal. pntd.0006105. PMid:29267276.

Bobrowiec PED, Lemes MR, Gribel R. Prey preference of the common vampire bat (Desmodus rotundus, Chiroptera) using molecular analysis. J Mammal. 2015;96(1):54-63. http://dx.doi.org/10.1093/jmammal/gyu002.

Bourhy H, Dautry-Varsat A, Hotez PJ, Salomon J. Rabies, still neglected after 125 years of vaccination. PLoS Negl Trop Dis. 2010;4(11):e839. http://dx.doi.org/10.1371/ journal.pntd.0000839. PMid:21152052.

Braga GB, Grisi-Filho JH, Leite BM, de Sena EF, Dias RA. Predictive qualitative risk model of bovine rabies occurrence in Brazil. Prev Vet Med. 2014;113(4):536-46. http://dx.doi. org/10.1016/j.prevetmed.2013.12.011. PMid:24433635.

Brasil. Ministério da Agricultura, Pecuária e Abastecimento. Secretaria de Defesa Agropecuária. Controle da raiva dos herbívoros: manual técnico [Internet]. Brasília: MAPA; 2009 [cited 2020 Aug 26]. 124 p. Available from: www.gov.br/ agricultura/pt-br/assuntos/sanidade-animal-e-vegetal/saudeanimal/programas-de-saude-animal/raiva-dos-herbivorose-eeb/copy2_of_MANUAL_RAIVAHERBVOROS2009.pdf.

Bredt A, Araújo FAA, Caetano J Jr, Rodrigues MGR, Yoshizawa M, Sodré Silva MM, Harmani NMS, Massunaga PNT, Bürer SP, Porto VAR, Uieda W. Morcegos em áreas urbanas e rurais: manual de manejo e controle. 2a. ed. Brasília: Fundação Nacional de Saúde, Ministério da Saúde; 1998 [cited 2020 Aug 27]. 117 p. Available from: https:// fr.scribd.com/doc/72930141/Morcegos-em-areas-urbanase-rurais-manual-de-manejo-e-controle\#scribd.
Condori-Condori RE, Streicker DG, Cabezas-Sanchez C, Velasco-Villa A. Enzootic and epizootic rabies associated with vampire bats, Peru. Emerg Infect Dis. 2013;19(9):1463-9. http://dx.doi.org/10.3201/eid1909.130083. PMid:23969087.

Davis BM, Rall GF, Schnell MJ. Everything you always wanted to know about rabies virus (but were afraid to ask). Annu Rev Virol. 2015;2(1):451-71. http://dx.doi.org/10.1146/ annurev-virology-100114-055157. PMid:26958924.

Dias RA, Nogueira VS Fo, Goulart CS, Telles IC, Marques GH, Ferreira F, Amaku M, Ferreira JS No. Modelo de risco para circulação do vírus da raiva em herbívoros no estado de São Paulo, Brasil. Rev Panam Salud Publica. 2011;30(4):370-6. PMid:22124696.

Erkert HG. Ecological aspects of bat activity rhythms. In: Kunz TH, editor. Ecology of bats. Boston: Springer; 1982. p. 201-42. http://dx.doi.org/10.1007/978-1-4613-3421-7_5.

Estrada A, Coates-Estrada R. Bats in continuous forest, forest fragments and in an agricultural mosaic habitat-island at Los Tuxtlas, Mexico. Biol Conserv. 2002;103(2):237-45. http://dx.doi.org/10.1016/S0006-3207(01)00135-5.

Estrada A, Jiménez C, Rivera A, Fuentes E. General bat activity measured with an ultrasound detector in a fragmented tropical landscape in Los Tuxtlas, Mexico. Anim Biodiv Conserv [Internet]. 2004 [cited 2020 Aug 27];27(2):5-13. Available from: http://abc.museucienciesjournals.cat/files/ ABC-27-2-pp-5-13.pdf.

Gilbert AT, Petersen BW, Recuenco S, Niezgoda M, Gómez J, Laguna-Torres VA, Rupprecht C. Evidence of rabies virus exposure among humans in the Peruvian Amazon. Am J Trop Med Hyg. 2012;87(2):206-15. http://dx.doi.org/10.4269/ ajtmh.2012.11-0689. PMid:22855749.

Gomes MN, Uieda W. Abrigos diurnos, composição de colônias, dimorfismo sexual e reprodução do morcego hematófago Desmodus rotundus (E. Geoffroy) (Chiroptera, Phyllostomidae) no Estado de São Paulo, Brasil. Rev Bras Zool. 2004;21(3):629-38. http://dx.doi.org/10.1590/S010181752004000300025 .

Goodwin GG, Greenhall AM. A review of the bats of Trinidad and Tobago: description, rabies infection, and ecology. B Am Mus Nat Hist [Internet]. 1961 [cited 2020 Aug 26];122(3):187-302. Available from: http://hdl.handle. net/2246/1270. 
Hansen MC, Potapov PV, Moore R, Hancher M, Turubanova SA, Tyukavina A, Thau D, Stehman SV, Goetz SJ, Loveland TR, Kommareddy A, Egorov A, Chini L, Justice CO, Townshend JRG. High-resolution global maps of 21st-century forest cover change. Science. 2013;342(6160):850-3. http://dx.doi. org/10.1126/science.1244693. PMid:24233722.

Instituto Nacional de Estadística e Informática - INEI. IV Censo Nacional Agropecuario (CENAGRO): sistema de consulta de resultados censales: cuadros estadísticos [Internet]. Lima, Peru: INEI; 2012 [cited 2020 Aug 26]. Available from: http://censos.inei.gob.pe/cenagro/tabulados.

Johnson N, Aréchiga-Ceballos N, Aguilar-Setien A. Vampire bat rabies: ecology, epidemiology and control. Viruses. 2014;6(5):1911-28. http://dx.doi.org/10.3390/v6051911. PMid:24784570.

Kingston T. Response of bat diversity to forest disturbance in southeast Asia: insights from long-term research in Malaysia. In: Adams R, Pedersen S, editors. Bat evolution, ecology, and conservation. New York: Springer; 2013. http:// dx.doi.org/10.1007/978-1-4614-7397-8_9.

Lee DN, Papeş M, Van Den Bussche RA. Present and potential future distribution of common vampire bats in the Americas and the associated risk to cattle. PLoS One. 2012;7(8):e42466. http://dx.doi.org/10.1371/journal. pone.0042466. PMid:22900023.

Mayen F. Haematophagous bats in Brazil, their role in rabies transmission, impact on public health, livestock industry and alternatives to an indiscriminate reduction of bat population. J Vet Med B Infect Dis Vet Public Health. 2003;50(10):469-72. http://dx.doi.org/10.1046/j.14390450.2003.00713.x. PMid:14720182.

Medina A, Harvey CA, Merlo DS, Vílchez S, Hernández B. Bat diversity and movement in an agricultural landscape in Matiguás, Nicaragua. Biotropica. 2007;39(1):120-8. http:// dx.doi.org/10.1111/j.1744-7429.2006.00240.x.

Mialhe PJ. Preferential prey selection by Desmodus rotundus (E. Geoffroy, 1810, Chiroptera, Phyllostomidae) feeding on domestic herbivores in the municipality of São Pedro, SP. Braz J Biol. 2014;74(3):579-84. http://dx.doi.org/10.1590/ bjb.2014.0086. PMid:25296205.

QGIS Development Team. QGIS Geographic Information System [Internet]. Bern: QGIS; 2016 [cited 2020 Aug 26]. Available from: www.qgis.org.
Rosemberg M. La ganadería bovina en Perú [Internet]. Panama city, Panama: Veterinaria Digital; 2018 [cited 2020 Aug 27]. Available from: www.veterinariadigital.com/ articulos/la-ganaderia-bovina-en-peru.

Schneider MC, Romijn PC, Uieda W, Tamayo H, Silva DF, Belotto A, Silva JB, Leanes LF. Rabies transmitted by vampire bats to humans: an emerging zoonotic disease in Latin America? Rev Panam Salud Publica. 2009;25(3):2609. http://dx.doi.org/10.1590/S1020-49892009000300010. PMid:19454154.

Society for Range Management Rangeland Assessment and Monitoring Committee. Does size matter? Animal units and animal unit months. Rangelands. 2017;39(1):17-9. http://dx.doi.org/10.1016/j.rala.2016.12.002.

Streicker DG, Allgeier JE. Foraging choices of vampire bats in diverse landscapes: potential implications for land-use change and disease transmission. J Appl Ecol. 2016;53(4):1280-8. http://dx.doi.org/10.1111/1365-2664.12690. PMid:27499553.

Streicker DG, Recuenco S, Valderrama W, Benavides JG, Vargas I, Pacheco V, Condori-Condori RE, Montgomery J, Rupprecht CE, Rohani P, Altizer S. Ecological and anthropogenic drivers of rabies exposure in vampire bats: implications for transmission and control. Proc R Soc B. 2012;279:3384-92. http://dx.doi.org/10.1098/rspb.2012.0538.

Streicker DG, Winternitz JC, Satterfield DA, CondoriCondori RE, Broos A, Tello C, Recuenco S, Velasco-Villa A, Altizer S, Valderrama W. Host-pathogen evolutionary signatures reveal dynamics and future invasions of vampire bat rabies. Proc Natl Acad Sci USA. 2016;113(39):10926-31. http://dx.doi.org/10.1073/pnas.1606587113. PMid:27621441.

University of Maryland. Global Land Analysis \& Discovery. Global 2010 Tree Cover (30 m) [Internet]. College Park, MD: Department of Geographical Sciences. [date unknown] - [cited 2020 Aug 27]. Available from: https://glad.umd. edu/dataset/global-2010-tree-cover-30-m.

United States Geological Survey. EarthExplorer [Internet]. Reston: USGS; 2020 [cited 2020 Aug 26]. Available from: https://earthexplorer.usgs.gov.

Voigt CC, Kelm DH. Host preference of the common vampire bat (Desmodus rotundus; Chiroptera) assessed by stable isotopes. J Mammal. 2006;87(1):1-6. http://dx.doi. org/10.1644/05-MAMM-F-276R1.1. 
Financial Support: The authors would like to thank Jorge Mantilla from the National Service of Animal Health (SENASA) for helping to clarify some doubts about the official information. Francisco Miroslav Ulloa-Stanojlovic was supported by the National Fund for Scientific, Technological Development and Technological Innovation (FONDECYT), the funding branch of the National Council for Science, Technology and Technological Innovation (CONCYTEC) Peru (Grant No. 003-2016-FONDECYT). This study was financed in part by the Coordination for the Improvement of Higher Education Personnel (CAPES) Finance Code 001. 